\title{
Prevalence of Hepatitis C Virus among the Healthy Blood Donors in the Department of Transfusion Medicine of a Teaching Hospital
}

\author{
Md. Mohimanul Hoque, ${ }^{1}$ Md. Shafiqul Islam, ${ }^{2}$ Md. Azizul Haque, ${ }^{3}$ Amena Akter, ${ }^{4}$ \\ Mst. Musarrat Sultana, ${ }^{5}$ Md. Amzad Hossain Sardar, ${ }^{6}$ Md. Rofiqul Islam ${ }^{7}$
}

\begin{abstract}
Background: Hepatitis $\mathrm{C}$ virus (HCV) has been described as a significant causative agent of chronic hepatitis since its characterization in 1989. HCV may remain latent or become activated, leading to persistent infections and, in some cases, cirrhosis and hepatocellular carcinoma HCV is most commonly transmitted through direct contact with infected blood. Other, less common routes of transmission of $\mathrm{HCV}$ include sexual intercourse with infected individuals and mother to child transfer.

Materials and Methods: This is a cross-sectional descriptive type study which was carried out in the Department of Transfusion Medicine of Rajshahi Medical College Hospital for six months from January to June 2014 to determine the prevalence of hepatitis C virus in the apparently healthy blood donors. All apparently healthy blood donors fulfilling the inclusion and exclusion were included in this study. The blood donors who were positive for anti-HCV antibodies were seropositive. Anti HCV antibody screened by ICT and confirmed by ELISA method.

Results: Among 1712 apparently healthy blood donors, 36 (2.1\%) donors were anti-HCV positive, and $1676(97.9 \%)$ donors were negative. The mean age of the study patients was 34.05 years (SD $= \pm 8.79$ ). $66.7 \%$ of the study patients were male, whereas $33.3 \%$ of donors were female among the 36 blood donors.

Conclusion: It is absolutely necessary to avoid the transmission of infection from repeat donors who are asymptomatic HCV positive. Policymakers and public health stakeholders need to introduce and implement further preventive measures targeting the routes of HCV transmission.
\end{abstract}

Keywords: Hepatitis C virus, healthy blood donors

TAJ 2021; 34: No-2: 24-31

\section{Introduction}

Hepatitis $\mathrm{C}$ virus (HCV) is a meticulous factor of liver disease and one of the most important health issues worldwide ${ }^{1,2}$. Hepatitis $\mathrm{C}$ has approximately 175 million global disease burdens which represent almost $3 \%$ of the whole population in the world, each year 3 to 4 million new patients with $\mathrm{HCV}$ are diagnosed. HCV remains endemic in many countries of the world ${ }^{3,4,5}$. Statistics based on the general healthy population revealed that HCV has $5.3 \%$ seroprevalence in Pakistan, $2.2 \%$ in

\footnotetext{
${ }^{1}$ Assistant Professor, Department of Medicine, Rajshahi Medical College, Rajshahi

2 Assistant Professor, Department of Gastroenterology, Rajshahi Medical College, Rajshahi

${ }^{3}$ Associate Professor, Department of Medicine, Rajshahi Medical College, Rajshahi

${ }^{4}$ Medical Officer, Department of Transfusion Medicine, Rajshahi Medical College Hospital, Rajshahi

${ }^{5}$ Resident Physician (Paediatrics), Rajshahi Medical College Hospital, Rajshahi

${ }^{6}$ Assistant Professor, Department of Medicine, Rajshahi Medical College, Rajshahi

${ }^{7}$ Assistant Professor, Department of Hepatology, Rajshahi Medical College, Rajshahi
} 
Turkey, and $7.7 \%$ in Zimbabwe. ${ }^{6,7,8}$ Hepatitis C virus infection is not the main factor of mortality in the first decade of infection ${ }^{9}$. Poverty, high-risk sexual behavior, having less than 12 years of education, and having been divorced or separated are linked to an increased risk of infection ${ }^{10,11}$ Sexual transmission of the virus appears to be an inefficient means ${ }^{12}$ However, coinfection with HIV-1 appears to increase the risk of both sexual and maternal-fetal transmission of $\mathrm{HCV}^{10,13,14}$ Virus can be recovered from the saliva of infected persons, ${ }^{15}$ and although chimpanzees have been experimentally infected by the injection of saliva from HCV-infected persons, ${ }^{16}$ casual household contact and contact with the saliva of infected persons also appear to be very inefficient modes of transmission 15,17 Nosocomial transmission has been documented, such as from patient to patient by a colonoscope, ${ }^{18}$ during dialysis,${ }^{19}$ and during surgery. ${ }^{20,21}$ Until relatively recently, blood transfusion posed a major risk of $\mathrm{HCV}$ infection in developed countries. The introduction in 1990 and 1992 of improved blood-screening measures based on the detection of $\mathrm{HCV}$ antibodies has dramatically decreased the risk of transfusionassociated HCV infection. Diagnostic tests for $\mathrm{HCV}$ infection are divided into serologic assays for antibodies and molecular tests for viral particles. Screening assays based on antibody detection have markedly reduced the risk of transfusion-related infection, and once persons seroconvert, they usually remain positive for $\mathrm{HCV}$ antibodies. However, recent data indicate that the level of HCV antibodies decreases gradually over time in the few patients in whom infection spontaneously resolves. In a cohort with a welldocumented common source and known time of infection, assays for antibodies to $\mathrm{HCV}$ became negative after 18 to 20 years in 18 of 43 patients with spontaneous clearance of viremia. ${ }^{22}$ This finding may also suggest that the true incidence of acute $\mathrm{HCV}$ infection with spontaneous clearance has been underestimated since not all infected persons have persistent serologic evidence of infection.

\section{Materials and Methods}

This is a cross-sectional descriptive type study that was carried out in the Department of Transfusion Medicine of Rajshahi Medical College Hospital for six months from January to June 2014 to determine the prevalence of the hepatitis $C$ virus in apparently healthy blood donors. A purposive sampling technique was used. All apparently healthy blood donors fulfilling the inclusion and exclusion criteria were included in this study. Professional blood donors and donors with comorbidities like hypertension, diabetes, etc., were excluded from this study. The blood donors who were positive for anti-HCV antibodies were seropositive. Anti HCV antibody screened by ICT and confirmed by ELISA method.

\section{Results}

Table 1: Prevalence of hepatitis $C$ virus in the apparently healthy blood donors $(n=1712)$

$\begin{array}{cccc} & & \text { Number } & (\%) \\ \text { Anti HCV BY } & \text { Positive } & 36 & 2.1 \\ \text { ELISA } & \text { Negative } & 1676 & 97.9 \\ \text { (Confirmatory) } & \text { Total } & 1712 & 100\end{array}$

Among 1712 apparently healthy blood donors, 36 (2.1\%) donors were anti-HCV positive, and 1676 $(97.9 \%)$ donors were negative. The mean age of the study patients was 34.05 years $(\mathrm{SD}= \pm 8.79)$. The age distribution of patients revealed the highest $47.2 \%$ in 29 to 39 years. The mean age is 34.05 ( $\mathrm{SD} \pm 8.79) .66 .7 \%$ of the study patients were male, whereas $33.3 \%$ of donors were female among the 36 blood donors. People in all occupations were susceptible to $\mathrm{HCV}$, but higher percentages were found in day labor (25\%) and service holder (25\%). Among the infected people, $66.7 \%$ were married, and 30.6\% were unmarried. Donors were Illiterate (38.9\%), and donors with up to primary education were $25 \%$, up 
to higher secondary was $13.9 \%$, up to SSC were $11.1 \%$, and among the graduates were $11.1 \%$. Among the HCV-positive blood donors, about $58.3 \%$ were from urban, and $41.7 \%$ were from rural areas. Among 36 HCV-positive blood donors, about $16.7 \%$ were intravenous drugs user, and $83.3 \%$ of donors did not use the intravenous drug. About $22.2 \%$ of donors had a history of previous blood or blood product infusion, and $77.8 \%$ had no history of previous blood or blood product infusion. In this study, 24 male blood donors were positive for anti HCV; among them, $41.1 \%$ had self-shaving practice, and $58.9 \%$ were used to shave in the barbershop. In this study, out of 9 married female blood donors, $44.4 \%$ had a history of normal vaginal delivery of their child, and $55.6 \%$ had a history of caesarian section. In this study, 22.2 $\%$ of blood donors had a history of extramarital sexual relations. 50\% HCV positive blood donors Serum ALT levels were elevated less than two times normal, $16.6 \%$ were elevated more than two times normal, and $33.3 \%$ were within the normal limit.

Table 2: Demographic profile of positive case ( $\mathrm{n}-36)$ :

Patient characteristics

Frequency $(\mathbf{n}=36)$

12

17

3

4

$34.05 \pm 8.79$

Mean \pm SD

Sex

Male

Female

Occupation

Farmer

Student

Day labor

Service( GO/NGO)

Housewife

\section{Marital status}

Married

Unmarried

Others
24

12
33.3

47.2

11.1

8.3

66.7

33.3
Percentage

16.7

5.6

25

25

19.4
66.7

30.6

2.7 
Patient characteristics

\section{Education}

\begin{tabular}{|c|c|c|}
\hline Illiterate & 14 & 38.9 \\
\hline Primary & 9 & 25 \\
\hline $\mathrm{SSC}$ & 4 & 11.1 \\
\hline HSC & 5 & 13.9 \\
\hline Graduate & 4 & 11.1 \\
\hline Residence & & \\
\hline Urban & 21 & 58.3 \\
\hline $\begin{array}{l}\text { Rural } \\
\text { IV drugs }\end{array}$ & 15 & 41.7 \\
\hline Users & 6 & 16.7 \\
\hline $\begin{array}{l}\text { Non-users } \\
\text { Previous blood or blood } \\
\text { product infusion }\end{array}$ & 30 & 83.3 \\
\hline Present & 8 & 22.2 \\
\hline Absent & 28 & 77.8 \\
\hline Shaving behavior & Frequency $(n=24)$ & Percentage \\
\hline Self & 10 & 41.1 \\
\hline Barber & 14 & 58.9 \\
\hline Total & 24 & 100 \\
\hline
\end{tabular}

\section{Percentage}

Frequency $(n=36)$

Table 4: Prevalence of hepatitis $C$ virus in healthy female blood donors in relation with the mode of their child delivery $(n=9)$

\begin{tabular}{lll}
\hline mode of delivery & Frequency $(\mathrm{n}=9)$ & Percentage \\
\hline NVD & 4 & 44.4 \\
C/S & 5 & 55.6 \\
Total & 9 & 100 \\
\hline
\end{tabular}


Table 5: Prevalence of hepatitis $C$ virus in healthy blood donors in relation with their multiple sexual partners $(n=36)$

\begin{tabular}{lcl}
\hline Multiple sexual partners & Frequency $(\mathrm{n}=36)$ & Percentage \\
\hline Present & 8 & 22.2 \\
Absent & 28 & 77.8 \\
Total & 36 & 100 \\
\hline
\end{tabular}

Table 6: Prevalence of hepatitis $\mathrm{C}$ virus in healthy blood donors in relation with their serum ALT level ( $\mathrm{n}$ $=36$ )

\begin{tabular}{lcl}
\hline ALT level & Frequency $(\mathrm{n}=36)$ & Percentage \\
\hline Normal & 12 & 33.3 \\
$<$ Twice & 18 & 50 \\
$>$ Twice & 6 & 16.7 \\
Total & 36 & 100 \\
\hline
\end{tabular}

\section{Discussion}

In this study, an attempt has been made to define the seroprevalence of the Hepatitis $\mathrm{C}$ virus among the 1712 healthy donor population. I got $36(2.1 \%)$ were anti-HCV-positive blood donors. The overall proportion of $\mathrm{HCV}$ seropositivity among blood donors is almost the same as in Indonesia, $2.1 \%{ }^{23}$ and relatively lower than Saudi Arabia, 3.2\% ${ }^{24}$ Brazil, $2.9 \%{ }^{25}$, and substantially lower than $6.5 \%$ reported from Thailand. ${ }^{26} \mathrm{HCV}$ seroprevalence among blood donors in this study is slightly greater than the reported figures of $0.9-1.3 \%$ from Italy $^{27}, 0.35 \%$ from UK ${ }^{28}$, and $0.54 \%$ from USA ${ }^{29}$. HCV prevalence in the US blood donors is significantly lower than corresponding estimates of $1.8 \%$ in the general population, reflecting the efficacy of donor risk factor exclusion policies ${ }^{29}$, ${ }^{30}$. In a study done in a community of India, ${ }^{31}$ anti$\mathrm{HCV}$ seropositivities were found $1 \%$. A study done in Orissa reported anti-HCV seroprevalence was $1.98 \%$. Strategies of exclusion of donors on known risk factors history may play a substantial role in the reduction of post-transfusion $\mathrm{HCV}$ infection in recipients of blood transfusion. There is a lack of the same type of studies in our community with a large population that can identify the actual prevalence of $\mathrm{HCV}$. In this study, we also observed that a higher percentage of $\mathrm{HCV}$ blood donors were day labor (25\%), a significantly higher percentage of them were illiterate $(38.9 \%)$, and married $(66.7 \%)$. Some risk factors like shaving behavior of the male blood donors who use common shaving materials were also significant, who used to shave in the barbershop with common shaving materials had a higher prevalence $(58.9 \%)$, mode of delivery of the child of the female blood donors was also important, higher prevalence $(45.6 \%)$ was seen among the female who had cesarean delivery than normal vaginal delivery. ${ }^{32}$ The most common risk factors studied in our donors for acquiring $\mathrm{HCV}$ infection were sharing shaving kits or visiting a roadside barber $(62 \%)$. This history was elicited more in rural than urban blood donors. Alanine transferase levels were found to be elevated in a total of $66.7 \%$ of our anti-HCV-positive blood donors. In a community-based study from India ${ }^{32}$, 
ALT levels were found to be elevated in $87 \%$ of blood donors, thus indicating chronic hepatitis in the majority of the blood donors biochemically. On serial follow-up of these anti-HCV-positive blood donors, the majority of them showed fluctuations in their ALT levels. In another community-based study in India ${ }^{33}$, it has been observed that only 31 percent showed ALT elevation. This apparent difference in HCV causing more severe liver injury in our donors needs future studies on $\mathrm{HCV}$ genotype infecting our population. The sample size of seroreactive donors who responded for confirmation of the diagnosis and follow-up was small, and thus, future studies on larger sample size would help in drawing valid and better conclusions.

The overall prevalence and age, sex relation is consistent with the observations of Chukwurah, Ogbodo \& Obi ${ }^{34}$, where they found out of the 1229 blood donors screened in our center for HCV between 2005 and 2009, 25 were found to be seropositive, giving an overall prevalence rate of $2.0 \%$. There were 1001 males and 228 females with a male to female ratio of $4.4: 1$. The mean age of the blood donors was $30.1 \pm 8$.5years. In this study, I found that the mean age of the study patients was 34.05 years $(\mathrm{SD}= \pm 8.79), 66.7 \%$ of the study patients were male, and $16.7 \% \mathrm{HCV}$ positive blood donors were intravenous drugs user. Shrestha et al. ${ }^{35}$ also found transmissible transfusion infections were dominant among male blood donors compared to female blood donors; male to female ratio was 2:1. Higher HCV seroprevalence among males compared to females was statistically significant. HCV prevalence was highest among blood donors 31 to 40 years age group, Prevalence of $\mathrm{HCV}$ was relatively higher among the intravenous drug users that were similar with this study. In this study, we observed that $22.2 \%$ of donors had a history of previous blood or blood product infusion, $16.7 \%$ of $\mathrm{HCV}$ positive blood donors were intravenous drugs user, and about $22.2 \%$ of blood donors had a history of extramarital sexual relations. Akhtar et al ${ }^{36}$ also seroprevalence of $\mathrm{HCV}$ in these donors was $1.8 \%$, cases were more likely than controls to have reported past hospitalization once or more than once. The use of a glass syringe to give therapeutic injection increased the risk of $\mathrm{HCV}$ seropositive significantly more among cases than in controls. A significant number of cases had reported sexual contact with commercial sex workers. Chaudhary et al. ${ }^{37}$ and Jeremiah et al. ${ }^{38}$ have also shown a similar pattern of age, sex distribution of the HCV positive blood donors, but the overall prevalence of $\mathrm{HCV}$ was less $(0.6 \%)$ in earlier and more $(5 \%)$ in the later than this study. Makroon et al. ${ }^{39}$ also observed similar age, sex distribution with a low prevalence, Damaty et al. ${ }^{40}$ described similar age, sex distribution, more from urban areas than rural areas, but the prevalence of HCV among blood donors of different blood banks of Egypt was very high $(10.6 \%)$.

\section{Conclusion}

It is absolutely necessary to avoid the transmission of infection from repeat donors who are asymptomatic HCV positive. As the blood bank population may underestimate the prevalence of $\mathrm{HCV}$ in comparison to the national survey, this type of study should be done in a community with a large population. Policymakers and public health stakeholders need to introduce and implement further preventive measures targeting the routes of $\mathrm{HCV}$ transmission.

\section{References}

1. Asselah T, Estrabaud E, Bieche I Lapalus M, De Muynck S, Vidaud, M et al. : Hepatitis C: viral and host factors associated with non-response to pegylated interferon plus ribavirin. Liver Int 2010, ISSN 1478-3223.

2. Alter MJ: Epidemiology of hepatitis $C$ virus infection. World J Gastroenterol 2007, 13(17):2436-41.

3. Butt $A A$ : Hepatitis $C$ virus infection: the new global epidemic. Expert Rev Anti Infect Ther 2005, 3:241-9.

4. Soriano V, Peters MG, Zeuzem S. New Therapies for Hepatitis C Virus Infection. Clinical Infectious Diseases 2009, 48:313-20.

5. Koziel M, Peters M: Viral hepatitis in HIV infection. N Engl J Med 2007, 356:1445-54.

6. Demirtürk N, Demirdal T, Toprak D, Altindiş $M$, Aktepe OC: Hepatitis B and C virus in West-Central Turkey: Seroprevalence in healthy individuals admitted to a university hospital for routine health checks. Turk J Gastroenterol 2006, 17:267-72. 
7. Gangaidzo IT, Moyo VM, Khumalo H, Saungweme T, Gomo Z, Rouault $T$ et al: Hepatitis $C$ virus in Zimbabwe. Cent Afr J Med 1997, 43:122-5.

8. Khokhar N, Gill ML, Malik GJ: General seroprevalence of hepatitis $C$ and hepatitis B virus infections in the population. J Coll Physicians Surg Pak 2004, 14:534-6.

9. Harris HE, Ramsay ME, Andrews N, Eldridge KP. The clinical course of hepatitis $C$ virus during the first decade of infection: cohort study. BMJ 2002, 324:16.

10.Thomas DL, Villano SA, Riester KA, Hershow R,Mofenson LM, Landesman SH et al. Perinatal transmission of hepatitis $\mathrm{C}$ virus from human immunodeficiency virus type 1-infected mothers: Women and Infants Transmission Study. J Infect Dis 1998;177: 1480-8.

11. Ohto H, Terazawa S, Sasaki N, Hino K, Ishiwata C, Kako $\mathrm{M}$ et al. Transmission of hepatitis $\mathrm{C}$ virus from mothers to infants. N Engl J Med 1994;330:744-50.

12. Wyld R, Robertson JR, Brettle RP Mellor J, Prescott $L$, Simmonds $P$. Absence of hepatitis $C$ virus transmission but frequent transmission of HIV-1 from sexual contact with doubly-infected individuals. J Infect 1997; 35:163-6.

13. Eyster ME, Alter HJ, Aledort LM Quan S, Hatzakis A, Goedert JJ. Heterosexual co-transmission of hepatitis $\mathrm{C}$ virus (HCV) and human immunodeficiency virus (HIV). Ann Intern Med 1991;115:764-8.

14. Soto B, Rodrigo L, Garcia-Bengoechea M, SanchezQuijano A, Riestra S, Arenas JI et al. Heterosexual transmission of hepatitis $\mathrm{C}$ virus and the possible role of coexistent human immunodeficiency virus infection in the index case: a multicentre study of 423 pairings. J Intern Med 1994;236:515-9.

15. Couzigou P, Richard L, Dumas F Schouler L, H Fleury $H$. Detection of HCV-RNA in saliva of patients with chronic hepatitis C. Gut 1993;34: Suppl:S59-S60.

16. Abe K, Kurata T, Shikata T, Sugitani M, Odaet $T$. Experimental transmission of non- $A$, non- $B$ hepatitis by saliva. J Infect Dis 1987;155:1078-9.

17. Sagnelli E, Gaeta GB, Felaco FM, Stroffolini T, Conti S, Glielmo A et al. Hepatitis $C$ virus infection in households of anti-HCV chronic carriers in Italy: a multicentre case-control study. Infection 1997;25:346-9.

18. Bronowicki J-P, Venard V, Botté C, Monhoven N, Gastin I, Choné $L$ et al. Patient-to-patient transmission of hepatitis $\mathrm{C}$ virus during colonoscopy. N Engl J Med 1997; 337:237-40.
19. Katsoulidou A, Paraskevis D, Kalapothaki V, Arvanitis D, Karayiannis $P$, Hadjiconstantiou $V$ et al. Molecular epidemiology of a hepatitis $C$ virus outbreak in a haemodialysis unit: Multicentre Haemodialysis Cohort Study on Viral Hepatitis. Nephrol Dial Transplant 1999;14:1188-94.

20. Esteban JI, Gómez J, Martell M, Cabot B, Quer J, Camps $\mathrm{J}$ et al. Transmission of hepatitis $\mathrm{C}$ virus by a cardiac surgeon. N Engl J Med 1996; 334:555-60.

21. Ross RS, Viazov S, Gross T, Hofmann F, Seipp HM, Roggendorf M. Transmission of hepatitis $C$ virus from a patient to an anesthesiology assistant to five patients. N Engl J Med 2000; 343:1851-4.

22. Takaki A, Wiese M, Maertens G, Depla E, Seifert U, Liebetrau $A$ et al. Cellular immune responses persist and humoral responses decrease two decades after recovery from a single- source outbreak of hepatitis C. Nat Med 2000;6:578-82.

23. Sulaiman HA, Julitasari, Sie A, Rustam M, Melani W, Corwin A et al. Prevalence of hepatitis B and C viruses in healthy Indonesian blood donors. Tran $\mathrm{R}$ Soc Trop Med Hyg 1995; 89: 167- 170.

24. Abdelaal M, Rowbottom D, Zawawi T, Scott T, Gilpin C. Epidemiology of hepatitis: a study of male blood donors in Saudi Arabia. Transfusion 1994; 34: 135137.

25. Patino-Sarcinelli F, Hyman J, Camacho LAB, Linhares DB, Azevedo JG. Prevalence and risk factors for hepatitis $C$ antibodies in volunteer blood donors in Brazil. Transfusion 1994; 34: 138-141.

26. Songsivilai S, Jinathongthai S, Wongsena W, Tiangpitayakorn C, Dharakul T. High prevalence of hepatitis $\mathrm{C}$ infection among blood donors in northeastern Thailand Am J Trop Med Hyg 1997; 57: 66-69.

27. Lai ME, Mazzoleni AP, Farci P, Melis A, Porru A, Orgiana $G$ et al. Markers of hepatitis $C$ virus infection in Sardinian blood donors: relationship with alanine aminotransferase levels. J Med Virol 1993; 41: 282-288.

28. Mutimer DJ, Harrison RF, O'Donnel KB, Shaw J, Martin BA, Atrah $\mathrm{H}$ et al . Hepatitis $\mathrm{C}$ virus infection in the asymptomatic British Blood donors. J Viral Hepat 1995; 2: 47-53.

29. Wang B, Schreiber GB, Glynn SA, Nass CC, Smith JW, Higgins MJ et al. Prevalence of transfusiontransmissible viral infections in first-time US blood donors by donation site. Transfusion 2003; 43(6): 705-712. 
30. Glynn SA, Kleinman SH, Schreiber GB, Busch MP,Wright DJ, Smith JW et al. Trends in incidence and prevalence of major transfusion-transmissible viral infections in United States blood donors, 1991 to 1996. JAMA 2000; 284: 229-350.

31. Makroo RN, Walia RS, Chowdhry M, Bhatia A, Hegde V, Rosamma NL. Seroprevalence of antiHCV antibodies among blood donors of north India Department of Transfusion Medicine, Indraprastha Apollo Hospitals, New Delhi, India; Indian J Med Res 138, July 2013, pp 125-128

32. Beenu T, Neelam M,. Chawla YK, Saluja K, Sharma $A$, Sharma RR et al. Prevalence \& significance of hepatitis $\mathrm{C}$ virus (HCV) seropositivityin blood donors Departments of Transfusion Medicine, Hepatology \& Immunopathology, Postgraduate Institute of Medical Education \& Research, Chandigarh, India; Indian J Med Res 124, October 2006, pp 431-438

33. Cantilena C, Van Raden M, Gibble J, Melpolder J, Shakil AO, Viladomiu $L$ et al. Routes of infection, viremia, and liver disease in blood donors found to have hepatitis $\mathrm{C}$ virus infection. N Engl J Med 1996; 334 : 1691-6.

34. Chukwurah EF, Ogbodo SO, Obi GO. Prevalence of Antibodies to Hepatitis C Virus in Blood Donors, South-Eastern Nigeria; Biomedical Research 2005; 16 (2): 133-135.

35. Shrestha AC, Ghimire P, Tiwari BR, Rajkarnikar M. Transfusion-transmissible infections among blood Nepal Central Blood Transfusion Service, Nepal Red Cross Society, Kathmandu, Nepal ;J Infect Dev Ctries 2009; 3(10):794-797.
36. Akhtar S, Younus M, Adil S, Jafri SH, Hassan F. Hepatitis $\mathrm{C}$ virus infection in asymptomatic male volunteer blood donors in Karachi, Pakistan; Department of Pathology and Microbiology, Aga Khan University; and Husaini Blood Bank, Karachi, Pakistan; Journal of Viral Hepatitis, 2004, 11, 527535

37. Chaudhary IA, Samiullah, Khan SS, Masood R, Sardar MA et al. Seroprevalence of Hepatitis B and $\mathrm{C}$ among the healthy blood donors at Fauji Foundation Hospital, Karachi; Pak J Med Sci 2007:23 (1) 64-67.

38. Jeremiah ZA, Koate B, Buseri F, Emelike F. Prevalence of antibodies to hepatitis $C$ virus in apparently healthy Port Harcourt blood donors ;Dept of Medical Laboratory Sciences, Niger Delta University, Wilberforce Island, Bayelsa State.; Blood transfuse;2008; 6;150-155.

39. Makroo RN, Walia RS, Chowdhry M, Bhatia A, Hegde V, Rosamma NL. Seroprevalence of antiHCV antibodies among blooddonors of north IndiaDepartment of Transfusion Medicine, Indraprastha Apollo Hospitals, New Delhi, India; Indian J Med Res 138, July 2013, pp 125-128.

40. Damaty SIEI, Hassan SK, Mohamed MK, Hosini MEI, Rekacewicz C, Fontanet A. Surveillance System for HCV Infection: Testing; Model Based on Blood Banks; Department of Community, Environmental and Occupational Medicine, Faculty of Medicine, Ain Shams University, Cairo, Egypt. 